\title{
Profit and cost efficiency in the Italian banking industry (2006-2011)
}

\author{
Francesco Aiello* • Graziella Bonanno \\ Department of Economics, Statistics and Finance, University of Calabria, Italy
}

Received: 26 August 2013

Revised: 14 October 2013

Accepted: 15 October 2013

\begin{abstract}
This study evaluates the cost and the profit efficiency of Italian banking sector over the period 2006-2011. Translog stochastic frontiers are used for this purpose. Following the intermediation approach, efficiency scores are computed from estimating a model with three inputs and three outputs. Results show that the average levels of cost and profit efficiency are both around $90 \%$ and they are quite stable over time. However, there is high heterogeneity in results. Differences have been found when banks are classified by size (efficiency tends to decrease with size), legal type (cooperatives perform better than others) and area (the best performers are in the North East of the country).
\end{abstract}

Keywords: banking, translog stochastic frontiers, cost and profit efficiency

JEL Classification Codes: G21, C13, D01

\section{Introduction}

An intense restructuring process of banking industry has occurred in most countries over the last two decades. It was aimed at fostering efficiency and financial stability. In Italy the reform started with the 1990 Amato-Carli Act, the coming into force of EU Directive II and the 1993 Consolidated Act (Angelini and Cetorelli 2004; Giannola 2009; Messori et al. $2003)^{1}$. All these norms have led to radical changes in the Italian banking sector. Over-time, there has been: a shift from state-owned to private banks; a marginalisation of banking foundations; a consolidation process involving the major Italian banks. The outcome of this process is also documented by the reduction in the number of banks (there were 1037 banks in 1993 and 706 in 2012) and the increase in bank branches (22133 in 1993 and 32875 in 2012).

\footnotetext{
*Corresponding author. E-mail: f.aiello@unical.it.

Citation: Aiello, F. and Bonanno, G. (2013) Profit and cost efficiency in the Italian banking industry (20062011), Economics and Business Letters, 2(4), 190-205.

${ }^{1}$ The process of institutional reforms has been enriched by other norms, such as the 2002 budget law, the 262/2005 law and the 353/2006 Legislative Decree.
} 
Given this circumstance, banks have re-examined their strategies to foster efficiency and face competition better. Thus, it is meaningful to investigate bank performance, given that the industry is now much more market-oriented than in the past. To this end, we use the Stochastic Frontier Approach (SFA) to measure the cost and profit efficiency of Italian banks and apply the specification proposed by Battese and Coelli (1995). ${ }^{2}$ An aspect of interest in the analysis is related to the period covered, the years between 2006 and 2011. This was a period of instability in financial markets which has not yet been studied in terms of the effects on the efficiency of Italian banks. This work fills this gap by considering a sample of about 700 banks observed annually from 2006 to 2011.

Despite the huge literature on bank efficiency - there are exhaustive surveys by Berger and Humphrey (1997) and Fethi and Pasourias, (2010) - few papers have focused on Italy (Battaglia et al., 2010; Dongili et al., 2008; Fontani and Vitali, 2007; Giannola et al., 1997; Giannola and Scarfiglieri, 1998; Girardone et al., 2004). In this regards the evidence is mixed, but three conclusions may be drawn. Larger banks attain lower efficiency levels. Banks' costefficiency is higher in the North of Italy than in the South. Cooperatives perform better than other banks in controlling costs. ${ }^{3}$

This study contributes to the debate by updating the analysis. We find that the average level of profit and cost efficiency of Italian banks was around 90\% over the period 2006-2011 However, efficiency was highly heterogeneous. Differences in results emerge when banks are classified by size (efficiency tends to decrease with size), legal type (cooperatives perform better than others) and area (the best performers are in the North East of Italy).

The paper is organised as follows. Section 2 presents the method. Section 3 describes the data and section 4 discusses the results. Section 5 concludes.

\section{Stochastic Frontier framework and banks' cost and profit frontiers}

The SFA is a stochastic method because it allows banks to be distant from the frontier also for randomness (Aigner et al., 1977; Meeusen and van de Broek, 1977). It differs from the Data Envelopment Analysis (DEA) which supposes that distance from the frontier is entirely due to inefficiency. Again, SFA assigns a distribution to the stochastic component of the model and, thus, allows to make inference. Inference, however, is not specific to SFA (Simar and Wilson 2000). A further advantage of SFA derives from the specification of Battese and Coelli (1995), which improves, in terms of consistency, previous modelling where one firstly estimates inefficiency using a frontier and, secondly, uses the estimated efficiency-score as the dependent variable in subsequent regression (Greene 1993). ${ }^{4}$

The following function $F_{c}$ (.) indicates the cost of producing an output $y$ given a price $w$, whereas $F_{p}($.$) states the profit obtainable from producing y$ at input price $w$.

\footnotetext{
${ }^{2}$ The choice of considering both dimension of efficiency overcomes the limits arising from analysing only one of them. Indeed, profit efficiency only gauges performance properly if banks' objectives are restricted to profit maximisation. However, banks tend to minimise costs. According to some authors profit efficiency is superior to cost efficiency "for evaluating the overall performance of the firm" (Berger and Humphrey, 1997; Berger and Mester, 1997; Fitzpatrick and McQuinn, 2005). This view is intuitively based on the fact that profit derives from the maximisation of a function which depends on revenues and costs. It must be also said that profit efficiency requires not only technical efficiency and both input and output allocative efficiency (as does the cost efficiency), but also an appropriate scale. Thus, banks cannot be profit efficient if they are scale inefficient (Berger and Mester, 1997)

${ }^{3}$ Giannola et al. (1997), Giannola and Scarfiglieri (1998), Girardone et al. (2004), Giordano and Lopes (2006), Giordano and Lopes (2012), Fontani and Vitali (2007), Dongili et al. (2008), Battaglia et al. (2010).

${ }^{4}$ As shown by Lensink and Meesters (2012) and Wang and Schmidt (2002), the two-step approach suffers from the fact that the inefficiency is assumed to be identically and independently distributed in the main frontier equation, while it depends on other variables in the inefficiency equation.
} 


$$
\begin{aligned}
& \operatorname{Cost}_{i t}=F_{c}(y, w) e^{v_{c}} e^{u_{c}} \\
& \text { Profit }_{i t}=F_{p}(y, w) e^{v_{p}} e^{-u_{p}}
\end{aligned}
$$

Eq. [2] is an alternative profit function since it depends on inputs and outputs, whereas actual profits depend on the prices of output. It uses the same variables as the cost function, implying that output-prices are free to vary (Huizinga et al., 2001). Exhaustive discussions on alternative versus traditional profit efficiency are in Berger and Mester (1997) and VanderVennet (2002).

From eq. [1], the efficiency is expressed as the ratio between the minimum cost of a potentially efficient bank and the cost actually observed:

$$
C E=\frac{F_{c}(y, w) e^{v_{c}}}{F_{c}(y, w) e^{v_{c}} e^{u_{c}}}=e^{-u_{c}}
$$

Similarly, profit efficiency is the ratio between the observed banks' profit and the maximum level of profit achievable in case of full efficiency

$$
P E=\frac{F_{p}(y, w) e^{v_{p}} e^{-u_{p}}}{F_{p}(y, w) e^{v_{p}}}=e^{-u_{p}}
$$

We use the translog function to model the form of frontiers. It satisfies the assumptions of non-negativity, concavity and linear homogeneity (Kumbhakar and Lovell, 2000). After taking into account the constraint of homogeneity ${ }^{5}$ in relation to input-prices $\left(\sum_{n} \gamma_{n}=1\right)$, the cost frontier in the log-linear ( $w_{r}$ is the price of deposits) is:

$$
\begin{aligned}
\log \left(\frac{\text { Cost }}{w_{r}}\right) & =\beta_{0}+\sum_{j} \beta_{j} \log y_{j}+\sum_{n} \gamma_{n} \log \frac{w_{n}}{w_{r}}+\frac{1}{2}\left[\sum_{j} \sum_{s} \beta_{j s} \log y_{j} \log y_{s}+\sum_{n} \sum_{q} \gamma_{n q} \log \frac{w_{n}}{w_{r}} \log \frac{w_{q}}{w_{r}}\right]+ \\
& +\sum_{n} \sum_{j} \alpha_{n j} \log \frac{w_{n}}{w_{r}} \log y_{j}+u+v
\end{aligned}
$$

where Cost is a bank's total costs; $y_{j}$ represents the $j$-th output; $w_{n}$ is the cost of the $n$-th input; $\beta, \gamma$ and $\alpha$ are the parameters to be estimated; $u$ is the inefficiency; $v$ is the random error.

With regards profits, the right-hand side replicates the cost function, while the dependent variable is banks' profit, expressed as $\log \left(\frac{\text { Profit }}{w_{r}}\right)$. As in Berger and Mester (1997), Bonin et al. (2005), Fitzpatrick and McQuinn (2005), Huizinga et al. (2001) and Maudos et al. (2002) we transform profits by adding the absolute value of minimum profit plus one to actual profits. This ensures that $\log ($ Profit $)=\log \left[\pi+\left|\pi^{\min }\right|+1\right]$ is defined in $[0,+\infty)$.

Finally, we assume that $\mathrm{v}_{i t}$ is normally distributed with mean zero and $\mathrm{u}_{i t}$ is distributed as a truncated normal. Again, $\mathrm{v}_{i t}$ and $\mathrm{u}_{i t}$ are independently and identically distributed:

$$
\begin{aligned}
& v_{i t} \sim \operatorname{iidN}\left(0, \sigma_{v}^{2}\right) \\
& u_{i t} \sim N^{+}\left(z^{\prime} \eta, \sigma_{u}^{2}\right)
\end{aligned}
$$

\footnotetext{
${ }^{5}$ Using a translog, linear homogeneity also requires standard symmetry $\left(\beta_{j s}=\beta_{s j}\right.$ and $\gamma_{n q}=\gamma_{q n}$ ) and linear restrictions of the cost (or profit) function $\left(\sum_{n} \gamma_{n q}=0\right.$ and $\left.\sum_{n} \alpha_{n j}=0\right)$.
} 
where $z^{\prime} \eta$ is the linear predictor of inefficiency. ${ }^{6}$ The inefficiency component is specified as:

$$
u_{i t}=\sum_{k=1}^{K} \eta_{k} z_{i t k}+e_{i t}
$$

where $z_{i t k}$ represents the $k$-th variable that affects inefficiency of the $i$-th bank; with $k=1, \ldots$, $K . t$ is time and $\mathrm{e}_{i t}$ the random component. In addition, the inequality $e \geq-z^{\prime} \eta$ ensures the non-negativity of $u$.

\section{Data and variables}

Data are from the Italian Banking Association (ABI). The period under scrutiny covers the period 2006-2011 because the implementation of International Accounting Standards (IAS) occurred in 2005 and the balance sheets before-and-after the IAS implementation are not comparable.

The sample is presented in table 1. Banks are 686 in 2006, 692 in 2007, 689 in 2008, 686 in 2009, 648 in 2010 and 631 in 2011. They represent, on average, more than $96 \%$ of banks operating in Italy. The sample is dominated by cooperatives (on average 63\% over-time), followed by corporations (32\%) and Popolari banks (6\%). ${ }^{7}$ Many banks are small and minor (92\% of the sample in 2006 and 94\% in 2011). Furthermore, the proportion of banks that have their headquarters in the North is $60 \%$ of the sample (20\% in the South). ${ }^{8}$ Banks' size ranges from 2,764 mln euro in 2006 to 3,312 mln euro in 2011. Corporations are the largest, followed by Popolari and cooperatives. When considering location, the big banks are generally in the north-western of Italy with a size of about 6,3 mln euro in 2011. This value is double that reported by banks in central and north-eastern Italy and nine times higher than southern-banks' size.

We estimate a three-inputs-three-outputs model referring to the intermediation approach (Sealey and Lindley, 1977). Table 2 displays the variables used in defining the frontiers, while table 3 presents the determinants of efficiency. Table 4 reports some descriptive statistics of the variables included in the cost and profit frontiers.

\footnotetext{
${ }^{6}$ As in many other recent papers - see, i.e., Battaglia et al. (2010) in the banking efficiency literature - the assumptions on $\mathrm{v}_{i t}$ and $\mathrm{u}_{i t}$ are those originally proposed by Battese and Coelli (1995), also because modeling other "possible correlated structures of the technical inefficiency effects and the random errors in the frontier" (Battese and Coelli, 1995, 327) goes beyond the scope of this work.

${ }^{7}$ The Popolari banks are a specific category of cooperative that, during the restructuring process occurred in Italy over the last two decades, have maintained their nature of cooperatives for what concerns some features (the one vote per capita, irrespective of the number of shares held by the shareholder) but were trasformed in profit-seeking companies.

${ }^{8}$ As proposed by the Bank of Italy, bank size is defined by considering loans and deposits, the number of employees and of branches, The territorial classification consists of: North-West (Liguria, Lombardy, Piedmont, Aosta Valley), North-East (Emilia-Romagna, Friuli-Venezia-Giulia, Trentino, Veneto); Centre (Lazio, Marche, Tuscany, Umbria), South-and-Islands (Abruzzo, Basilicata, Calabria, Campania, Molise, Apulia, Sicily and Sardinia).
} 
Table 1. Description of the sample. Number of banks* and size** by year

\begin{tabular}{|c|c|c|c|c|c|c|c|c|c|c|c|c|}
\hline & \multicolumn{2}{|c|}{2006} & \multicolumn{2}{|c|}{2007} & \multicolumn{2}{|c|}{2008} & \multicolumn{2}{|c|}{2009} & \multicolumn{2}{|c|}{2010} & \multicolumn{2}{|c|}{2011} \\
\hline & Banks & Size & Banks & Size & Banks & Size & Banks & Size & Banks & Size & Banks & Size \\
\hline Area & & & & & & & & & & & & \\
\hline North-West & 151 & 6,011 & 149 & 6,955 & 144 & 8,210 & 152 & 7,464 & 138 & 5,762 & 129 & 6,370 \\
\hline North-East & 241 & 1,636 & 242 & 1,884 & 242 & 1,877 & 239 & 2,045 & 231 & 2,883 & 230 & 3,020 \\
\hline Centre & 151 & 3,250 & 150 & 3,106 & 154 & 3,238 & 150 & 3,381 & 144 & 3,182 & 139 & 3,418 \\
\hline South & 143 & 725 & 151 & 701 & 149 & 712 & 145 & 768 & 135 & 742 & 133 & 736 \\
\hline Legal form & & & & & & & & & & & & \\
\hline Corporations & 218 & 7,327 & 218 & 7,845 & 222 & 8,593 & 233 & 8,082 & 207 & 8,001 & 193 & 8,879 \\
\hline CCB & 431 & 241 & 436 & 257 & 428 & 278 & 414 & 301 & 406 & 318 & 404 & 328 \\
\hline Popolari & 37 & 5,276 & 39 & 6,368 & 39 & 5,506 & 39 & 6,001 & 35 & 6,689 & 34 & 7,154 \\
\hline Size & & & & & & & & & & & & \\
\hline Minor & 514 & 277 & 520 & 244 & 521 & 281 & 517 & 296 & 496 & 342 & 489 & 344 \\
\hline Small & 118 & 2,393 & 119 & 2,623 & 118 & 2,801 & 121 & 2,958 & 109 & 2,790 & 102 & 3,120 \\
\hline Medium & 32 & 11,100 & 35 & 13,100 & 33 & 15,900 & 29 & 13,800 & 29 & 14,200 & 27 & 16,000 \\
\hline Large & 13 & 25,000 & 11 & 28,900 & 10 & 30,600 & 12 & 31,200 & 10 & 32,700 & 9 & 40,000 \\
\hline Major & 9 & 87,800 & 7 & 121,000 & 7 & 133,000 & 7 & 137,000 & 4 & 202,000 & 4 & 203,000 \\
\hline Total & 686 & 2,764 & 692 & 2,983 & 689 & 3,253 & 686 & 3,268 & 648 & 3,177 & 631 & 3,312 \\
\hline
\end{tabular}

Note:

* The number of banks changes year-by-year because (i) the dataset does not comprise the balance-sheet of some minor and small banks in 2010 and 2011; (ii) some banks have ceased to operate; (iii) few banks were involved in a very limited number of merges and acquisitions.

** Average value of total assets, expressed as the ratio between the total assets and the number of banks of each group. Constant values in mln of euro - NIC Index Istat, base year $=1995$.

Source: our calculations based on data from ABI. 
Table 2. Definition of the variables included in the cost and profit functions

\begin{tabular}{|c|c|c|}
\hline Variables & Name & Description \\
\hline$y_{1}$ & Loans & $\begin{array}{l}\text { Loans to customers. It includes current accounts, } \\
\text { repurchase agreements, mortgages, credit cards, personal } \\
\text { loans and salary-backed loans, transactions relating to } \\
\text { financial leasing and factoring, business loans, structured } \\
\text { debt securities and other securities }\end{array}$ \\
\hline$y_{2}$ & Commission Income & $\begin{array}{l}\text { Revenues arising from non-traditional loans and deposits } \\
\text { of banks. It includes incomes from trading of financial } \\
\text { instruments and currencies, custody and administration } \\
\text { of securities, business consulting, management of } \\
\text { insurance products, collection and payment services, } \\
\text { collection services. }\end{array}$ \\
\hline$y_{3}$ & Securities & Sum of loans to other banks, equities and bonds \\
\hline$x_{1}$ & Labour & Number of employees \\
\hline$x_{2}$ & Capital & $\begin{array}{l}\text { Gross Banking Product, expressed as the sum of loans, } \\
\text { direct and indirect funding. }\end{array}$ \\
\hline$x_{3}$ & Deposits & Debts to customers \\
\hline$w_{1}$ & Labour cost & $\begin{array}{l}\text { Ratio between the personnel expenses and the number of } \\
\text { employees }\end{array}$ \\
\hline$w_{2}$ & Cost of capital & $\begin{array}{l}\text { Ratio between the other expenses (commission expenses, } \\
\text { operating costs, depreciation of fixed assets, the } \\
\text { administrative costs that do not relate to personnel } \\
\text { expenses and the interest expenses that do not relate to } \\
\text { those calculated on deposits) and the Gross Banking } \\
\text { Product }\end{array}$ \\
\hline$w_{3}$ & Cost of deposits & $\begin{array}{l}\text { Ratio between the interest expenses and the debts to } \\
\text { customers }\end{array}$ \\
\hline $\operatorname{Costs}(y, w)$ & Total costs & $\begin{array}{l}w_{1} x_{1}+w_{2} x_{2}+w_{3} x_{3}=\text { Administrative expenses }+ \\
\text { Depreciation of fixed assets }+ \text { Interest expenses }+ \\
\text { Operating costs }+ \text { Commission expenses }\end{array}$ \\
\hline Profits $(y, w)$ & Total profits & $\log ($ Profit $)=\log \left[\pi+\left|\pi^{\min }\right|+1\right]$ \\
\hline
\end{tabular}


Table 3. Definition of variables included in the inefficiency equation

\begin{tabular}{|c|c|c|}
\hline Variables & Name & Description \\
\hline$z_{1}$ & Credit Quality & $\begin{array}{l}\text { Ratio between bad loans and total loans for each } \\
\text { areas according to the location of customers. Source: } \\
\text { Bank of Italy }\end{array}$ \\
\hline$z_{2}$ & Solvency index & $\begin{array}{l}\text { Ratio between the regulatory capital and the risk- } \\
\text { weighted assets for each areas. It is a proxy of the } \\
\text { risk faced by banks and it takes into account the } \\
\text { directions in the Basel regulations. } \\
\text { Risk-weights consider the operational risk (the risk of } \\
\text { loss due to errors in the management of ordinary } \\
\text { banking activities), market risk (the risk of loss due } \\
\text { to the change in value for financial instruments) and } \\
\text { credit risk (risk of loss due to insolvent } \\
\text { counterparties) }\end{array}$ \\
\hline$z_{3}$ & $\begin{array}{l}\text { Herfindahl- } \\
\text { Hirschman index } \\
(\mathrm{HH})\end{array}$ & $\begin{array}{l}\text { It is calculated by squaring the market share of each } \\
\text { bank and then summing the resulting numbers. } \\
\text { Market shares are expressed as the ratio between the } \\
\text { total assets of each bank and the total assets of all } \\
\text { banks operating in any geographical macro-area. It is } \\
\text { used as proxy of industry concentration }\end{array}$ \\
\hline$z_{4}$ & FTSE & $\begin{array}{l}\text { FTSE refers to the Italian banks listed on the Milan } \\
\text { Stock Exchange }\end{array}$ \\
\hline $\begin{array}{l}d 2006, d 2007, d 2008 \\
d 2009 d 2010\end{array}$ & Time & $\begin{array}{l}\text { Annual dummy variables. } 2011 \text { is the controlling } \\
\text { group-year }\end{array}$ \\
\hline$d \_c o r p, d \_p o p$ & Legal form & $\begin{array}{l}\text { Dummies for legal form. CCB is the controlling } \\
\text { group }\end{array}$ \\
\hline $\begin{array}{l}\text { d_smallest, } \quad d \_m e d, \\
d \_l a r g e, d \_m a j o r\end{array}$ & Size & $\begin{array}{l}\text { Dummies for size. small-banks is the controlling } \\
\text { group }\end{array}$ \\
\hline$d \_n w, d \_c e n t r e, d \_s o u t h$ & $\begin{array}{l}\text { Geographical } \\
\text { location }\end{array}$ & $\begin{array}{l}\text { Dummies for geographical areas. North-East is the } \\
\text { controlling group }\end{array}$ \\
\hline
\end{tabular}

Table 4. Average values of input and output (2006-2011)

(constant values in mln of euro - NIC Index Istat, base year = 1995)

\begin{tabular}{|c|c|c|c|c|c|}
\hline Variables & Obs. & Mean & S.D. & Min & Max \\
\hline Cost & 3766 & 161456.60 & 856024 & 378.2148 & 20100000 \\
\hline$\Pi$ & 3766 & 10226.17 & 108520 & -1040415 & 4395613 \\
\hline Profit & 3766 & 1050642 & 108520 & 1 & 5436029 \\
\hline $\mathrm{y}_{1}=$ loans to customers & 3766 & 1712072 & 8435175 & 1.45 & 182000000 \\
\hline $\mathrm{y}_{2}=$ commission income & 3766 & 27212.08 & 133176 & 0.72 & 2880022 \\
\hline $\mathrm{y}_{3}=$ securities & 3766 & 716470.30 & 5922604 & 206.47 & 154000000 \\
\hline $\mathrm{w}_{1}=$ labour cost & 3758 & 53.14 & 20.50 & 7.12 & 712.77 \\
\hline $\mathrm{w}_{2}=$ cost of capital & 3766 & 0.0595 & 1.0283 & 0.000048 & 44.81 \\
\hline $\mathrm{w}_{3}=$ cost of deposits & 3741 & 0.0135 & 0.0344 & 0.000008 & 1.25 \\
\hline
\end{tabular}




\section{Econometric results}

The estimates of cost and profit frontiers are in table $5 .{ }^{9}$ One meaningful result regards gamma, which is the ratio between the variance of the inefficiency and the variance of the composite error. The estimated gamma parameter is always 0.99 indicating that all the distance from the frontiers is due to inefficiency. This evidence is confirmed by the Likelihood Ratio test, which verifies the correct model specification of a SFA. It considers the $\mathrm{H}_{\mathrm{o}}$ that all the parameters in eq. [8] are equal to zero: if this hypothesis is accepted, then the OLS estimates will be consistent because the composite error comprises only randomness. Results indicate that the LR is 805.13 and 4570 in cost and profit frontiers respectively and, therefore, $\mathrm{H}_{\mathrm{o}}$ is rejected at $1 \%$ (table 5).

Something that is immediately evident from the inefficiency model is that all variables are significant (table 6). The positive coefficient of $z_{1}$ suggests that low credit quality results in high inefficiency. ${ }^{10}$ The negative coefficient of solvency index $\left(z_{2}\right)$ indicates that banks' cost and profit efficiency increases when banking risk is low. The effect of market concentration $\left(z_{3}\right)$ on efficiency differs according to the frontier. The coefficient is negative in cost frontier, implying that a higher concentration allows higher cost efficiency levels to be reached. ${ }^{11}$ The opposite holds when considering profit, where the estimated inverse relationship between profits and concentration indicates that Italian banks fail, on average, to benefit from the revenue side, in spite of the increasing market-shares. This might be due to the competitive pressures from operating in a more-liberalized market. The estimated negative relationship between FTSE and inefficiency means that an increase in the index induces a reduction in inefficiency. As regards yearly dummies, we find that in 2006, 2007 and 2008 inefficiency was lower than in 2011. The opposite holds for 2009 and 2010.

The positive coefficients associated with territorial dummies highlight the role of location: banks in north-eastern Italy perform better than others, whatever the frontier. Moreover, the estimations reveal that southern banks perform less well than north-eastern institutions, but better than those in the Centre and North-West. It is also important to underline that cooperatives are the best performing type of banks. Mixed results are found when considering dummies associated with size, where the effect varies according to the frontier.

\footnotetext{
${ }^{9}$ We implement a LR test to verify the correctness of the translog. Under $\mathrm{H}_{0}$ there is the Cobb-Douglas model, which we always reject at $1 \%$.

${ }^{10}$ In line with the bad management hypothesis, the increased cost efficiency is a result of cost savings in screening and monitoring activities. This, however, has negative consequences on credit-quality (Berger and De Young, 1997).

${ }^{11}$ Similar results are in Fontani and Vitali (2007), but contrast with Turati (2008), according to which a higher concentration involves lower cost efficiency levels. However, they consider the Herfindahl-Hirschman at national level, while we refer to territorial markets.
} 
Table 5. Cost and profit frontiers of Italian banks

Translog estimates in 2006-2011

\begin{tabular}{|c|c|c|}
\hline & Cost & Profit \\
\hline$\beta_{0}$ & $-5.44 * * *$ & $10.18 * * *$ \\
\hline$\beta_{1}$ & $0.73 * * *$ & 0.02 \\
\hline$\beta_{2}$ & $-0.20 * * *$ & $-0.29 * * *$ \\
\hline$\beta_{3}$ & $0.38 * * *$ & $0.16 * * *$ \\
\hline$\gamma_{1}$ & $1.60 * * *$ & $1.18 * * *$ \\
\hline$\gamma_{2}$ & 0.03 & -0.05 \\
\hline$\beta_{11}$ & $0.04 * * *$ & $0.01 * * *$ \\
\hline$\beta_{12}$ & $-0.06 * * *$ & $-0.03 * * *$ \\
\hline$\beta_{13}$ & $-0.03 * * *$ & $0.05 * * *$ \\
\hline$\beta_{22}$ & $0.03 * * *$ & $0.02 * * *$ \\
\hline$\beta_{23}$ & $0.02 * * *$ & $-0.07 * * *$ \\
\hline$\beta_{33}$ & $0.01 * * *$ & $0.03 * * *$ \\
\hline$\gamma_{11}$ & $-0.05 * * *$ & -0.002 \\
\hline$\gamma_{12}$ & -0.004 & -0.02 \\
\hline$\gamma_{22}$ & $0.05 * * *$ & $0.06 * * *$ \\
\hline$\alpha_{11}$ & $-0.06 * * *$ & $-0.03 * * *$ \\
\hline$\alpha_{12}$ & $0.07 * * *$ & $0.08 * * *$ \\
\hline$\alpha_{13}$ & $-0.02 *$ & $-0.06 * * *$ \\
\hline$\alpha_{21}$ & $0.07 * * *$ & $0.03 * * *$ \\
\hline$\alpha_{22}$ & $-0.05 * * *$ & $-0.03 * * *$ \\
\hline$\alpha_{23}$ & $-0.002 * * *$ & 0.01 \\
\hline$\sigma^{2}$ & $119.43^{*}$ & $260.38 * * *$ \\
\hline$\gamma=\frac{\sigma_{u}^{2}}{\sigma^{2}}$ & $0.9997 * * *$ & $0.9999 * * *$ \\
\hline Log-likelihood & 363.15 & 1557.89 \\
\hline \multirow[t]{2}{*}{ LR test } & $805.13 *$ & $4570.00 *$ \\
\hline & $(34.2)^{+}$ & $(34.2)+$ \\
\hline
\end{tabular}

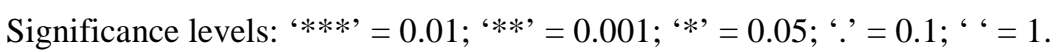
+ LR critical value as tabulate by Kodde and Palm (1986)

Source: see table 1 
Table 6. Cost and profit inefficiency for Italian banks Estimates over the 2006-2011 period

\begin{tabular}{|c|c|c|}
\hline & Cost & Profit \\
\hline $\mathrm{z}_{1}=$ bad loans & $615.77 *$ & $1580.20^{* * *}$ \\
\hline $\mathrm{z}_{2}=$ solvency index & $-868.05^{*}$ & $-733.66 * * *$ \\
\hline $\mathrm{z}_{3}=\mathrm{H}-\mathrm{H}$ index & $-2875.70^{*}$ & $4728.90 * * *$ \\
\hline $\mathrm{z}_{4}=\mathrm{FTSE}$ & $-0.03^{*}$ & $-0.09 * * *$ \\
\hline $\mathrm{d} 2006$ & $-105.64 *$ & $-236.19 * * *$ \\
\hline $\mathrm{d} 2007$ & $-73.35^{*}$ & $-658.29 * * *$ \\
\hline $\mathrm{d} 2008$ & $-859.18 *$ & $-4062.70 * * *$ \\
\hline d2009 & $163.84 *$ & $-213.31 * * *$ \\
\hline $\mathrm{d} 2010$ & $121.89 *$ & $-1196.20 * * *$ \\
\hline d_corp & $684.34^{*}$ & $3004.90 * * *$ \\
\hline d_pop & $892.63 *$ & $2555.40 * * *$ \\
\hline d_minor & $-65.13 *$ & $16.50 * * *$ \\
\hline d_med & $-402.49 *$ & $760.80 * * *$ \\
\hline d_large & $-170.87 *$ & $1004.60 * * *$ \\
\hline d_major & $152.38^{*}$ & $1114.10 * * *$ \\
\hline d_nw & $607.00 *$ & $273.02 * * *$ \\
\hline d_centre & $262.75^{*}$ & $107.54 * * *$ \\
\hline d_south & $144.99 *$ & $157.71 * * *$ \\
\hline
\end{tabular}

We find that the cost and profit efficiencies are both slightly higher than $90 \%$ in 20062011. By considering costs, it emerges that banks would have needed only $90 \%$ of the inputs used in offering banking services. They earned $90 \%$ of their potential profits: a $10 \%$ recovery of profitability would have been possible without increasing inputs. On average, this indicates that Italian banks perform similarly when they control costs or generate profits. We can see from table 8 that this holds even year-by-year: the average level of efficiency is $91 \%$ in both cases in 2006, declines up to 2008 and shows a slight recovery in the two subsequent years. In 2011, cost and profit efficiency-scores are around 90\%, a lower value than that of 2010 . While the average values of cost and profit efficiency are comparable, a certain heterogeneity exists between and within groups. The density function of cost efficiency differs from that of profit: profit efficiency is more dispersed than cost efficiency: standard deviations are 0.1162 and 0.0825 respectively. Again, the median cost efficiency is $92.4 \%$, while it is $94.54 \%$ for profits. Finally, for $1 \%$ of banks, cost efficiency ranges from $4.89 \%$ to $50 \%$, while the upper value of profit efficiency is $34.41 \%$ for $1 \%$ of banks (figure 1 and table 7 ).

Marked differences emerge when disaggregating the analysis by year and bank category (table 8). Whit regards the banks' type, we find that cooperatives perform better than others in both frontiers and every year. Over the 2006-2011 period, cooperatives register a cost inefficiency of $3.3 \%$ and a profit inefficiency of $4.1 \%$. These are much lower values than those estimated for corporations, which are $14 \%$ inefficient, whatever the frontier, and Popolari banks, which have a gap of $17,1 \%$ from the cost frontier and almost $13 \%$ in the case of profits. Over time, we see a common decline at the beginning of the period, a recovery in 2009 and 2010 and a new loss of efficiency in 2011. These time-changes do not alter the 
stylised-fact according to which cooperatives gain more in generating profits than in controlling costs (although the gap in efficiency scores is marginal and disappears in 2011). The same applies for Popolari banks, although their efficiency is always lower than that registered for cooperatives. The picture changes for corporations, which show different patterns: except for 2010, their cost efficiency is always higher than their profit efficiency. Interestingly, at the end of the period, the distance between profit and cost behaviour increased, as a consequence of the sharp reduction in 2011 profitability.

Three facts emerge when classifying banks by size. Firstly, minor banks perform well: inefficiency is less than $7 \%$ in profitability and $8.5 \%$ in costs. Thus they make better use of inputs and outputs than any other group. The same thing applies for small-banks for profits, while mixed evidence is found from cost-side (where small-banks might reduce inputs by $14,53 \%$, a value close to that $(14,16 \%)$ observed for large-banks and much higher than the cost inefficiency of medium-banks $(10,22 \%)$. Secondly, data indicate that efficiency decreases when size increases. This scale-effect is evident in profitability in 2009 and 2011, whereas, in the other years, it applies for the first four bank-groups. A noteworthy fact is that profit efficiency in $2006-2011$ is $93.19 \%$ for minor-banks, $87.29 \%$ for small-banks, $72.86 \%$ for medium-banks and $60.01 \%$ for large-banks. The last group is that of major-banks, which registers a profit efficiency of $63.98 \%$, a higher value than that observed for large-banks, but sharply lower than that estimated for any other sub-sample. Similarly, a size-effect is revealed on the cost-side: with the exception of small-banks, efficiency is $91.56 \%$ for minor-banks, $89.78 \%$ for medium-sized banks, 85.85 for large-banks and only $77.60 \%$ for major-banks. This relationship between size and cost efficiency is at work in every year. Another aspect regards the fact that cost and profit efficiencies record very narrow values for minor-smallbanks (with cost efficiency slightly higher than profit efficiency). The contrary holds for medium-large-major banks which perform better when controlling costs than when producing profits. The difference in efficiency scores is high at any time and assumes remarkable numbers for 2011 when banks tended to improve their behaviour in managing costs and experienced a drastic worsening in profitability (table 8).

Figure 1. Density of cost and profit efficiency

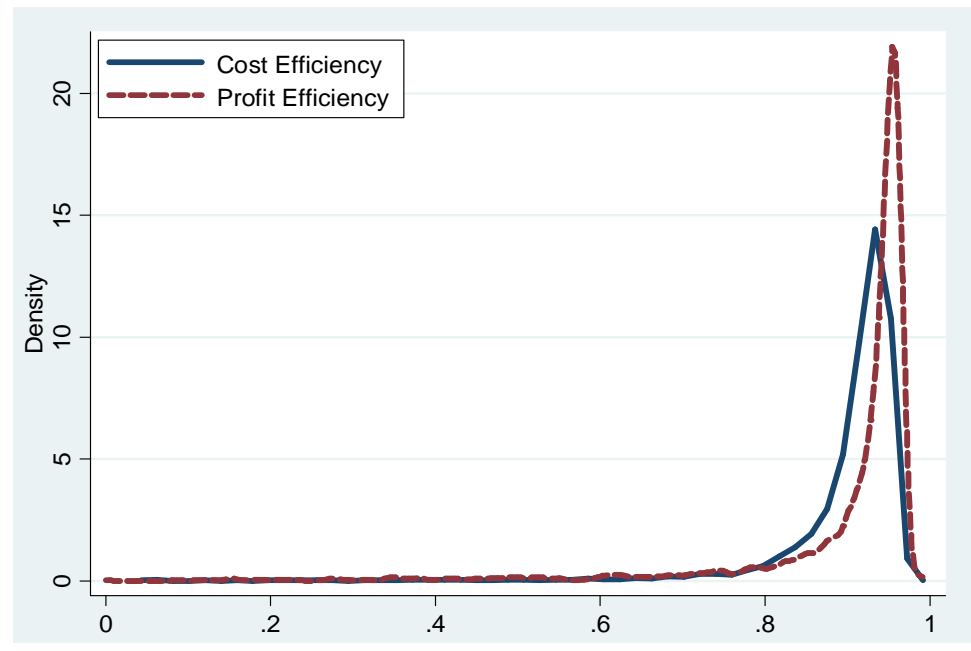


Table 7. Some descriptive statistics of cost and profit efficiency scores (2006-2011)

\section{Cost Efficiency}

\begin{tabular}{|c|c|c|c|c|}
\hline & Percentiles & Smaller values & & \\
\hline $1 \%$ & 0.5008 & 0.0490 & & \\
\hline $5 \%$ & 0.7830 & 0.0548 & & \\
\hline $10 \%$ & 0.8387 & 0.0612 & & \\
\hline $25 \%$ & 0.8950 & 0.0672 & Obs & 3741 \\
\hline \multirow[t]{3}{*}{$50 \%$} & 0.9245 & & Mean & 0.9021 \\
\hline & & & Std. & 0.08 \\
\hline & & Larger values & & \\
\hline $75 \%$ & 0.9413 & 0.9737 & & \\
\hline $90 \%$ & 0.9523 & 0.9788 & Variance & 0.0068 \\
\hline $95 \%$ & 0.9566 & 0.9801 & Skewness & -486.57 \\
\hline $99 \%$ & 0.9643 & 0.9855 & Kurtosis & 3.595 .15 \\
\hline
\end{tabular}

\section{Profit Efficiency}

\begin{tabular}{llllr} 
& Percentiles & Smaller values & & \\
$1 \%$ & 0.3441 & 0.000001 & & \\
$5 \%$ & 0.68178 & 0.0872 & & \\
$10 \%$ & 0.8140 & 0.1142 & & 3741 \\
$25 \%$ & 0.9112 & 0.1190 & Obs & 0.9048 \\
$50 \%$ & 0.9454 & & Mean & 0.11 \\
& & & Std. & \\
& & Larger values & & \\
$75 \%$ & 0.9571 & 0.9898 & & Variance \\
$90 \%$ & 0.9629 & 0.9905 & Skewness & -3.729 .905 \\
$95 \%$ & 0.9656 & 0.9908 & Kurtosis & 1.896 .607 \\
$99 \%$ & 0.9713 & 0.9909 & & \\
\hline \hline
\end{tabular}

Source: see table 1 
Table 8. Cost and profit efficiency of Italian banks by legal form, size and area (2006-2011)

\begin{tabular}{|c|c|c|c|c|c|c|c|}
\hline & 2006 & 2007 & 2008 & 2009 & 2010 & 2011 & 2006-20 \\
\hline \multicolumn{8}{|l|}{ Cost Efficiency } \\
\hline All sample & 0.9156 & 0.8955 & 0.8766 & 0.9008 & 0.906 & 0.9207 & 0.9021 \\
\hline \multicolumn{8}{|l|}{ Legal form } \\
\hline Corporations & 0.8751 & 0.8557 & 0.8203 & 0.8634 & 0.8703 & 0.8866 & 0.8608 \\
\hline Popolari & 0.8583 & 0.8182 & 0.7799 & 0.8106 & 0.8419 & 0.8782 & 0.8290 \\
\hline Cooperative Banks & 0.9378 & 0.9203 & 0.9129 & 0.9256 & 0.9263 & 0.9402 & 0.9270 \\
\hline \multicolumn{8}{|l|}{ Size } \\
\hline Minor & 0.9286 & 0.9117 & 0.8996 & 0.9123 & 0.9151 & 0.9278 & 0.9156 \\
\hline Small & 0.8675 & 0.8438 & 0.8005 & 0.8612 & 0.8748 & 0.8874 & 0.8547 \\
\hline Medium & 0.9117 & 0.8806 & 0.8607 & 0.9032 & 0.9092 & 0.9290 & 0.8978 \\
\hline Large & 0.8753 & 0.8581 & 0.7734 & 0.8779 & 0.8552 & 0.9236 & 0.8584 \\
\hline Major & 0.8551 & 0.7745 & 0.6759 & 0.7787 & 0.7881 & 0.8586 & 0.7760 \\
\hline \multicolumn{8}{|l|}{ Area } \\
\hline North West & 0.8696 & 0.8503 & 0.8315 & 0.8681 & 0.8794 & 0.8857 & 0.8635 \\
\hline North East & 0.9388 & 0.9138 & 0.8974 & 0.9230 & 0.9394 & 0.9448 & 0.9258 \\
\hline Centre & 0.9183 & 0.9054 & 0.8800 & 0.8999 & 0.8855 & 0.9172 & 0.9007 \\
\hline South & 0.9163 & 0.8983 & 0.8816 & 0.8959 & 0.8940 & 0.9174 & 0.9000 \\
\hline
\end{tabular}

Profit Efficiency

\begin{tabular}{|c|c|c|c|c|c|c|c|}
\hline All sample & 0.9191 & 0.8993 & 0.8814 & 0.9102 & 0.9298 & 0.8930 & 0.9048 \\
\hline \multicolumn{8}{|l|}{ egal form } \\
\hline Corporations & 0.8436 & 0.7962 & 0.7731 & 0.8293 & 0.8685 & 0.7844 & 0.8138 \\
\hline Popolari & 0.9105 & 0.8734 & 0.8345 & 0.8692 & 0.9187 & 0.8658 & 0.8762 \\
\hline Cooperative Banks & 0.9529 & 0.9497 & 0.9383 & 0.9511 & 0.9570 & 0.9459 & 0.9490 \\
\hline
\end{tabular}

Size

$\begin{array}{rlllllll}\text { Minor } & 0.9398 & 0.9320 & 0.9154 & 0.9368 & 0.9470 & 0.9232 & 0.9319 \\ \text { Small } & 0.8909 & 0.8565 & 0.8413 & 0.8747 & 0.9108 & 0.8687 & 0.8729 \\ \text { Medium } & 0.7895 & 0.6892 & 0.6275 & 0.7712 & 0.8302 & 0.6789 & 0.7286 \\ \text { Large } & 0.6783 & 0.5959 & 0.5444 & 0.6525 & 0.6840 & 0.4066 & 0.6001 \\ \text { Major } & 0.8225 & 0.7152 & 0.6719 & 0.5718 & 0.7718 & 0.2391 & 0.6398\end{array}$

Area

\begin{tabular}{rlllllll} 
North West & 0.8746 & 0.8320 & 0.8093 & 0.8590 & 0.8992 & 0.8334 & 0.8499 \\
North East & 0.9464 & 0.9298 & 0.9157 & 0.9367 & 0.9505 & 0.9172 & 0.9325 \\
Centre & 0.8998 & 0.8865 & 0.8642 & 0.9022 & 0.9084 & 0.8790 & 0.8894 \\
South & 0.9346 & 0.9254 & 0.9104 & 0.9229 & 0.9452 & 0.9237 & 0.9264 \\
\hline
\end{tabular}

Source: see table 1 


\section{Concluding remarks}

By using the SFA on a single sample of Italian banks, this study provides evidence on the likely mis-estimation involved when considering exclusively cost or profit efficiency. On average, no biased image of efficiency appears to occur given that cost and profit efficiency scores are both around $90 \%$. The picture changes when banks are classified into sub-groups. The groups of medium-large-major banks perform better when controlling costs than when generating profits. In such cases, studies which only focus on the cost frontier will overestimate the capability of the Italian banks to be efficient. With regards these groups of banks, it is worth emphasising that profit efficiency is quite a bit lower than cost efficiency. As the profit measure admits the existence of market power in setting the output-prices, the find that large-sized banks suffer the increase of competition. Two different results have been found for minor-small banks. They not only perform better than major-sized banks, but their cost and profit efficiency scores are similar: being small is an advantage in performing well. It also emerges that cooperatives attained the highest efficiency. They even perform better than the corporations, which are the banks involved in recent radical changes.

We may argue that large-sized banks face the competitive pressures in international markets more than the others do and this tends to reduce profit opportunities. Furthermore, the smallest banks and those organised as cooperatives perform well because, evidentially, they still enjoy a certain degree of monopolistic power in the restricted local markets where they operate.

\section{References}

Aigner, D., Lovell, C.A.K. and Schmidt, P. (1977) Formulation and estimation of stochastic frontier production function models, Journal of Econometrics, 6, 21-37.

Angelini, P. and Cetorelli, N. (2004) Gli effetti delle modifiche normative sulla concorrenza nel mercato creditizio, in Panetta F. (ed.): Il sistema bancario italiano negli anni novanta, Il Mulino: Bologna.

Barra, C., Destefanis, S. and Lubrano-Lavadera G. (2011) Risk regulation: the efficiency of Italian cooperative banks, Working Paper 290, Centre for Studies in Economics and Finance, University of Naples.

Battaglia, F., Farina, V., Fiordelisi, F. and Ricci, O. (2010) The efficiency of cooperative banks: the impact of environmental economic conditions, Applied Financial Economics, 20(17), 13631376.

Battese, G.E. and Coelli, T.J. (1995) A model for technical inefficiency effects in a stochastic frontier production function for panel data, Empirical Economics, 20(2), 325-332.

Berger, A.N. and De Young, R. (1997) Problem loans and cost efficiency in commercial banking, Journal Banking and Finance, 21, 849-870.

Berger, A.N. and Humphrey, D.B. (1997) Efficiency of financial institutions: international survey and directions for future research, European Journal of Operation Research, 98, 175-212.

Berger, A.N. and Mester, L.J. (1997) Inside the black box: what explains differences in the efficiencies of financial institutions?, Journal of Banking and Finance, 21, 895-947.

Bonin, J.P., Hasan, I. and Wachtel, P. (2005) Privatization matters: bank efficiency in transition countries, Journal of Banking and Finance, 29, 2155-2178.

Dongili, P., Rossi, S.P.S. and Zago, A. (2008) Efficienza e competitività delle banche italiane: un confronto con alcuni sistemi bancari europei, in Cella, G. and Zago A. (eds.): Competitività ed efficienza dell'economia italiana: fattori sistemici e valutazioni quantitative, Il Mulino: Bologna.

Dongili, P. and Zago, A. (2005) Bad loans and efficiencies in Italian bank, Working Paper 28, Dipartimento di Scienze Economiche, University of Verona. 
Fethi, M.D. and Pasourias, F. (2010) Assessing bank efficiency and performance with operational research and artificial intelligence techniques: a survey, European Journal of Operational Research, 204, 189-198.

Fiordelisi, F., Marques-Ibanez, D. and Molyneux, P. (2010) Efficiency and risk in European banking, Working Paper 1211, European Central Bank.

Fitzpatrick, P. and McQuinn, K. (2005) Measuring bank profit efficiency, Research Technical Paper 3, Economic Analysis and Research Department, Central Bank and Financial Services Authority of Ireland.

Fontani, A. and Vitali, L. (2007) L'efficienza di costo dei gruppi bancari italiani: un'analisi mediante frontiera stocastica, Working Paper, Department of Economics and Business, Luiss, Rome.

Giannola, A., Lopes, A., Ricci, C. and Scarfiglieri, G. (1997) Divari territoriali ed efficienza del sistema bancario italiano, in Quintieri B. (ed.): Finanza, istituzioni e sviluppo regionale, Il Mulino: Bologna.

Giannola, A. (2009) Bank mergers and credit allocation among Italian regions, in Silipo, D.B. (ed.): The banks and the Italian economy, Springer Phisyca-Verlag: Berlin Heidelberg.

Giannola, A. and Scarfiglieri, G. (1998) Cost vs profit efficiency, nontraditional activities and financial capital: a European perspective, Working Paper, 5th Financial Conference at Università di Tor Vergata, Rome.

Giordano, L. and Lopes, A. (2006) Preferenza al rischio e qualità degli impieghi come determinanti dell'efficienza del sistema bancario italiano, in Giannola, A. (ed.): Riforme istituzionali e mutamento strutturale. Mercati, imprese e istituzioni in un sistema dualistico, Carocci Editore: Rome.

Giordano, L. and Lopes, A. (2008) L'efficienza del sistema bancario italiano in un contesto dualistico e la rilevanza della dimensione e degli aspetti giuridici, Il Risparmio, 2.

Giordano, L. and Lopes, A. (2012) Le banche italiane tra consolidamento e recuperi di efficienza (1998-2008). Una promessa mantenuta?, in Giannola, A., Lopes, A. and Sarno, D. (eds.) I problemi dello sviluppo economico e del suo finanziamento nelle aree deboli, Carocci Editore, Rome.

Girardone, C., Molyneux, P. and Gardener, E.P.M. (2004) Analysing the determinants of bank efficiency: the case of Italian banks, Applied Economics, 36(3), 215-227.

Greene, W.H. (1993) The econometric approach to efficiency analysis, in The Measurement of Productivity Efficiency: Techniques and Applications, Oxford University Press: New York, 92-250.

Huizinga, H.P., Nelissen, J.H.M. and Vander Vennet, R. (2001) Efficiency effects of bank mergers and acquisitions in Europe, Working Paper 088/3, Tinbergen Institute.

Hunter, W.C. and Timme, S.G. (1995) Core deposits and physical capital: a re-examination of bank scale economies with quasi-fixed inputs, Journal of Money, Credit and Banking, 27(1), 165185.

Kodde, D. and Palm, F. (1986) Wald criteria for jointly testing equality and inequality restrictions, Econometrica, 54(5), 1243-1248.

Kumbhakar, S.C. and Lovell, C.A.K. (2000) Stochastic frontier analysis, Cambridge University Press.

Lensink, R. And Meesters, A. (2012) Institutions and bank performance: a stochastic frontier analysis, Oxford Bulletin of Economics and Statistics, forthcoming.

Maudos, J., Pastor, J.M., Perez, F. and Quesada, J. (2002) Cost and profit efficiency in European banks, Journal of International Financial Markets, Institutions and Money, 12(1), 33-58.

Meeusen, D. and van de Broek, J. (1997) Efficiency estimation from Cobb-Douglas production functions with composed error, International Economic Review, 18(2), 435-444.

Messori, M., Tamburini, R. and Zazzaro, A. (2003) Il sistema bancario italiano, Carocci Editore: Rome.

Sealey, C.W. and Lindley, J.T. (1977) Input, output and a theory of production and cost at depository financial institutions, The Journal of Finance, 32(4), 1251-1266.

Simar, L. and Wilson, P.W. (2000) A general methodology for bootstrapping in nonparametric frontier models, Journal of Applied Statistics, 27, 779-802. 
Turati, G. (2008) La valutazione del grado di concorrenza nell'industria bancaria negli anni Novanta, in Cella G. and Zago, A. (eds.): Competitività ed efficienza dell'economia italiana: fattori sistemici e valutazioni quantitative, Il Mulino: Bologna.

Vander Vennet, R. (2002) Cost and profit efficiency of financial conglomerates and universal banking in Europe, Journal of Money, Credit and Banking, 34, 254-282.

Wang, H.J. and Schimdt, P. (2002) One-step and two-step estimation of the effect of exogenous variables on technical efficiency levels, Journal of Productivity Analysis, 18, 129-144.

Williams, J. (2004) Determining management behaviour in European banking, Journal of Banking and Finance, 28, 2427-2460. 